\title{
Yield and quality of soybean seeds inoculated with Bacillus subtilis strains
}

\author{
Tauan R. Tavanti ${ }^{1}$, Renan F. R. Tavanti ${ }^{1}$, Fernando S. Galindo ${ }^{1}$, Isadora Simões ${ }^{1}$, Larissa S. Dameto ${ }^{1}$ \& \\ Marco E. de Sá ${ }^{1}$
${ }^{1}$ Universidade Estadual Paulista “Júlio de Mesquita Filho"/Faculdade de Engenharia de Ilha Solteira. Ilha Solteira, SP, Brasil. E-mails: tauanrt@outlook.com - ORCID: 0000-0001-6915-1702; renan.tavanti@hotmail.com - ORCID: 0000-0002-4496-9660; fs.galindo@yahoo.com.br (Corresponding author) - ORCID: 0000-0001-5118-7459; isadorasimoes97@gmail.com - ORCID: 0000-0003-3711-9489; larissasartori25@gmail.com - ORCID: 0000-0003-1921-0895; marcosa@agr.feis.unesp.br - ORCID: 0000-0002-0588-0356

\begin{abstract}
The use of growth-promoting bacteria can increase the yield and quality of seeds of several annual crops, such as soybean. Based on that, the present study aimed to evaluate the effects of the inoculation of Bacillus subtilis strains on seed treatment, evaluating the yield and quality of seeds of two soybean cultivars. The experiment was conducted in a conventional system, in an Oxisol of clayey texture, in a crop under sprinkler irrigation. The experimental design was randomized blocks, arranged in split plots with four repetitions. Treatments were composed, in the plots, of two soybean cultivars: M7110 IPRO and Brasmax Desafio RR. Within the levels of subplots, the treatments consisted of inoculation and doses of inoculant: Bacillus subtilis Pant001 strain at doses of 0, 2, 3, 4 and $5 \mathrm{~mL} \mathrm{~kg}^{-1}$, and QST713 strain at the recommended dose of $2 \mathrm{~mL} \mathrm{~kg}^{-1}$. Inoculation with the strains Pant001 and QST713 increased the yield of both soybean cultivars tested, besides improving seed quality due to the increase in the concentration of total storage proteins, seedling emergence percentage and seed vigor by the accelerated aging test.
\end{abstract}

Key words: Glycine max, plant growth-promoting bacteria, tetrazolium, storage proteins, seed vigor

\section{Produtividade e qualidade de sementes de soja inoculadas com estirpes de Bacillus subtilis}

RESUMO: A utilização de bactérias promotoras de crescimento pode promover incrementos de produtividade e qualidade de sementes de diversas culturas anuais, como a soja. Com base no exposto, com o presente estudo objetivou-se avaliar os efeitos da inoculação de estirpes de Bacillus subtilis no tratamento de sementes avaliando-se a produtividade e qualidade de sementes de duas cultivares de soja. O experimento foi conduzido em sistema convencional, num Latossolo Vermelho Distrófico de textura argilosa, em cultivo irrigado por aspersão. O delineamento experimental utilizado foi em blocos ao acaso dispostos em parcelas subdivididas com quatro repetições. Os tratamentos foram compostos, nas parcelas, por duas cultivares de soja: M7110 IPRO e Brasmax Desafio RR. Dentro dos níveis de subparcelas, os tratamentos foram constituídos de inoculação e doses de inoculante: Bacillus subtilis estirpe Pant001 nas doses de 0, 2, 3, 4 e $5 \mathrm{~mL} \mathrm{~kg}^{-1}$, e estirpe QST713, na dose recomendada de $2 \mathrm{~mL} \mathrm{~kg}^{-1}$. A inoculação com as estirpes Pant001 e QST713 proporcionou incrementos de produtividade em ambas cultivares de soja testadas, além de melhorar a qualidade das sementes em função do aumento na concentração de proteínas totais de reserva, porcentagem de emergência de plântulas e vigor de sementes pelo teste de envelhecimento acelerado.

Palavras-chave: Glycine max, bactérias promotoras de crescimento em plantas, tetrazólio, proteínas de reserva, vigor de sementes 


\section{INTRODUCTION}

Soybean (Glycine max (L.) Merrill) occupied 35,866 million hectares in the 2018/2019 season, with average grain yield of $3,207 \mathrm{~kg} \mathrm{ha}^{-1}$ (CONAB, 2019). To obtain high yields of soybean grains and considering the nitrogen $(\mathrm{N})$ demand of this crop, the biological fixation of $\mathrm{N}$ must work at maximum efficiency (Galindo et al., 2017; Moretti et al., 2018). In this context, the use of new technologies seeking to increase seed yield and quality becomes essential for the competitive agriculture and low carbon emissions (Sá et al., 2017). Thus, practices that minimize and/or optimize the use of inputs should be used in agricultural systems (Galindo et al., 2016).

Considering the limitations of biological $\mathrm{N}$ fixation (BNF) in the soybean crop and the benefits observed in several crops with the inoculation of Bacillus subtilis (soil free-living diazotroph), especially in the biological control of plants, production of natural antibiotics and protective effect against secondary soil phytopathogens (Araújo \& Marchesi, 2009; Kuhn \& Pascholati, 2010; Pavan et al., 2011; Jardin, 2015), in addition to growth and development of the root system, greater absorption of water and nutrients, it is inferred that the coinoculation with Bradyrhizobium and B. subtilis may favor the development of the crop and, therefore, the production and quality of its seeds (Hungria et al., 2013; Bishnoi et al., 2015; Singh et al., 2016; Tahir et al., 2017; Galindo et al., 2018).

In this context, given the lack of information on the effects of co-inoculation with Bradyrhizobium and B. subtilis under Brazilian Cerrado conditions on soybean seed quality and yield, this study has as the hypothesis that the co-inoculation of soybean seeds may favor the initial development, making this crop more vigorous and, consequently, increase the protein concentrations in its grains. In addition, it is suggested that the increase in the concentration of storage proteins has a direct effect on seed quality and vigor evaluated by the accelerated aging test. In view of the above, this study aimed to evaluate the effects of seed inoculation with Bacillus subtilis strains on two soybean cultivars (M7110 IPRO and Brasmax Desafio $\mathrm{RR})$, by assessing the yield and quality of the seeds produced.

\section{Material AND Methods}

The study was conducted in the 2017/2018 agricultural year, in an experimental area belonging to the Farm of Teaching, Research and Extension of Universidade Estadual Paulista located in the municipality of Selvíria, MS, Brazil (geographic coordinates $20^{\circ} 22^{\prime} \mathrm{S}$ and $51^{\circ} 22^{\prime} \mathrm{W}$, and $335 \mathrm{~m}$ of altitude). The soil of the experimental area was classified as Oxisol of clayey texture, and has been cultivated with annual crops for more than 28 years, under conventional cultivation. The history of agricultural cultivation prior to soybean sowing was crotalaria in the season and beans as winter crop.

According to Köppen's climatic classification, the climate of the region is considered Aw, tropical with two well-defined seasons, a rainy one in the summer and a dry one in the winter. Air temperature and mean annual precipitation is $25^{\circ} \mathrm{C}$ and $1330 \mathrm{~mm}$, respectively. The monthly values of rainfall and air temperature recorded during the experimental period are shown in Figure 1.

The experimental design was randomized blocks, arranged in split plots with four repetitions. The treatments were composed, in the plots, of two soybean cultivars: M7110 IPRO and Brasmax Desafio RR. Within the levels of subplots, the treatments consisted of inoculations and doses of inoculant: Bacillus subtilis Pant001 strain ( $1 \times 10^{9}$ colony-forming unit CFU mL $\mathrm{mL}^{-1}$ at doses of $0,2,3,4$ and $5 \mathrm{~mL} \mathrm{~kg}^{-1}$, and the QST713 strain ( $1 \times 10^{9}$ colony-forming unit CFU $\left.\mathrm{mL}^{-1}\right)$, at the recommended dose of $2 \mathrm{~mL} \mathrm{~kg}^{-1}$ of seeds to be sown. The experimental plot consisted of $5 \mathrm{~m}$ long rows spaced by $0.45 \mathrm{~m}$, totaling a usable area of $11.25 \mathrm{~m}^{2}$.

The soil chemical attributes in the arable layer (0-0.20 $\mathrm{m})$, determined before installing the soybean experiment, according to the methodology proposed by Raij et al. (2001), were: $23 \mathrm{mg} \mathrm{dm}^{-3}$ of P (resin); $2 \mathrm{mg} \mathrm{dm}^{-3}$ of S-SO $; 18 \mathrm{~g} \mathrm{dm}^{-3}$ of $\mathrm{OM} ; 5.3 \mathrm{pH}\left(\mathrm{CaCl}_{2}\right) ; \mathrm{K}, \mathrm{Ca}, \mathrm{Mg}, \mathrm{H}+\mathrm{Al}=1.4,17.0,15.0$ and $20.0 \mathrm{mmol}_{\mathrm{c}} \mathrm{dm}^{-3}$, respectively; $\mathrm{Cu}, \mathrm{Fe}, \mathrm{Mn}, \mathrm{Zn}(\mathrm{DTPA})=5.2$, $17.0,108.6$ and $0.9 \mathrm{mg} \mathrm{dm}^{-3}$, respectively; $0.18 \mathrm{mg} \mathrm{dm}^{-3}$ of $B$ (hot water) and $61 \%$ of base saturation.

Based on soil analysis and on the fertilizer recommendation for soybean (Ambrosano et al., 1997), fertilization at sowing was performed in the furrow using $70 \mathrm{~kg} \mathrm{ha}^{-1}$ of $\mathrm{P}_{2} \mathrm{O}_{5}$ and $40 \mathrm{~kg} \mathrm{ha}^{-1}$ of $\mathrm{K}_{2} \mathrm{O}$. The seeds were treated with the fungicides Carbendazim + Thiram at doses of $30+70 \mathrm{~g}$ of a.i. for every $100 \mathrm{~kg}$ of seeds, respectively, and cobalt and molybdenum were also applied at dose of $150 \mathrm{~mL} \mathrm{ha}^{-1}$ of the CoMo (15\% Mo and 1.5\% Co). After drying the seeds in the shade, rhizobia inoculation was performed at dose of $100 \mathrm{~mL} \mathrm{ha}^{-1}$ (strains: SEMIA 5019 [Bradyrhizobium elkanii] and SEMIA 5079 [Bradyrhizobium japonicum], with a guarantee of $6 \times 10^{9} \mathrm{CFU} \mathrm{\textrm {mL } ^ { - 1 }}$ ), together with the inoculation of Bacillus subtilis (treatments), using a clean concrete mixer for incorporation, carried out close to soybean sowing.

The experiment was installed on December 15, 2017, with the sowing of soybean cultivars (treatments), by manually

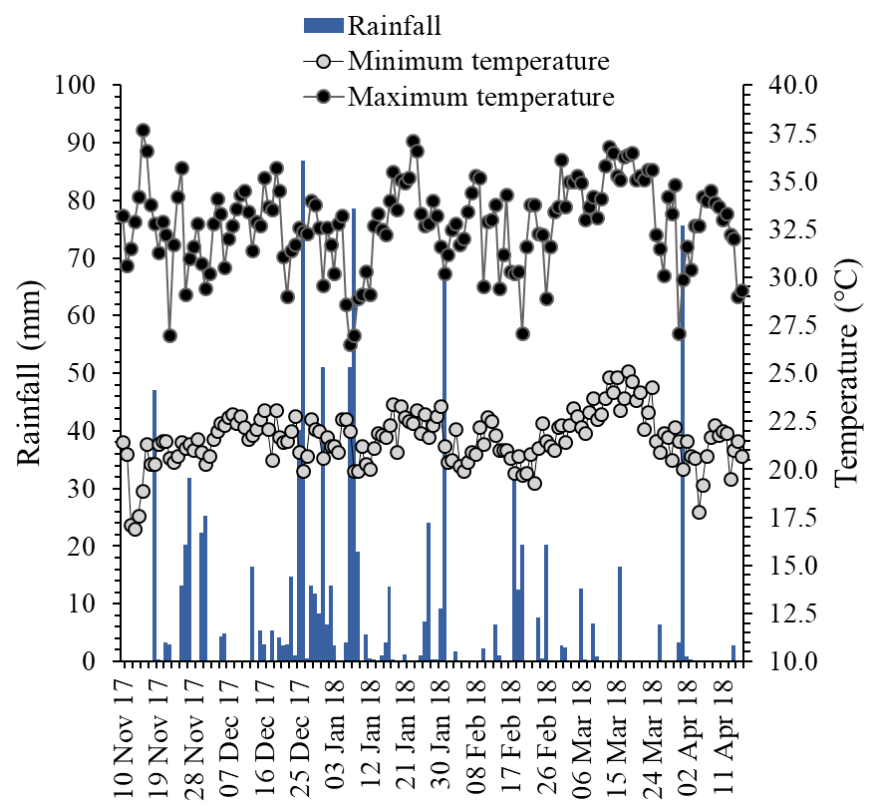

Figure 1. Precipitation, maximum temperature, minimum temperature and potential evapotranspiration recorded during the experimental period 
planting 13 seeds of each cultivar per meter, and the harvest was carried out on April 12, 2018, 118 days after sowing. Crop management practices followed the technical recommendations of cultivation and were homogeneously performed throughout the experimental area. The experimental area was irrigated by a cannon sprinkler, with a water depth of approximately $15 \mathrm{~mm}$, according to the need of the crop along the cycle.

At the end of the experiment, the plants contained within five meters in the two central rows of the plots were harvested. The material was subjected to a radial-flow threshing machine, in order to simulate the mechanized harvesting conditions of commercial seed production fields. Subsequently, the material was weighed and the values were adjusted to $13 \%$ moisture content, with results expressed in $\mathrm{t} \mathrm{ha}^{-1}$. The 100 -grain mass was quantified by weighing 100 grains, in four replicates. The results were expressed in grams and adjusted to $13 \%$ moisture content.

Protein fractions were quantified as previously described in Reis et al. (2018). In $15 \mathrm{~mL}$ Falcon tubes, $0.25 \mathrm{~g}$ of each dried and ground sample were weighed for sequential extraction of the storage protein fractions. For albumin extraction, $10 \mathrm{~mL}$ of deionized water were added and the tubes were stirred for one minute. After stirring, the tubes were taken to a refrigerated centrifuge at temperature of $4{ }^{\circ} \mathrm{C}$ at 9,000 rpm for $20 \mathrm{~min}$ to separate the phases. The supernatant was collected to quantify the albumin fraction. The precipitate was subjected to extraction with $10 \mathrm{~mL}$ of $5 \% \mathrm{NaCl}$ following the same procedures described previously, and the supernatant was collected to determine the globulin fraction. The precipitate was resuspended using $5 \mathrm{~mL}$ of $60 \%$ ethanol, and the supernatant was collected to quantify the prolamin fraction. Finally, the glutelin fraction was extracted, quantified from the extraction with $10 \mathrm{~mL}$ of $0.4 \% \mathrm{NaOH}$.

Albumin, globulin, prolamin and glutelin concentrations were determined according to the method of Bradford (1976), using the BSA ("bovine serum albumin") as the standard. 10 $\mu \mathrm{L}$ of albumin and globulin aliquots and $20 \mu \mathrm{L}$ of the prolamin and glutelin fractions and $5 \mathrm{~mL}$ of the Bradford reagent were pipetted into test tubes. Absorbance reading was performed in a spectrophotometer at $595 \mathrm{~nm}$ and the results were expressed in $\mathrm{mg}$ protein $\mathrm{g}^{-1} \mathrm{FM}$ (fresh mass at $13 \%$ moisture content). The total storage protein content was obtained by the sum of the albumin, globulin, prolamin and glutelin fractions.

Mechanical damage test was conducted using four subsamples of 100 whole seeds (excluding cracked and broken seeds), which were placed in plastic containers. Next, the previously prepared solution of hypochlorite $(25 \mathrm{~mL}$ of $5.25 \%$ sodium hypochlorite solution in one liter of deionized water) was added until it covered all the seeds. After $15 \mathrm{~min}$, the hypochlorite solution was drained and the seeds were washed in running water. Subsequently, they were placed on a paper towel to determine the number of seeds that soaked the solution, calculating the percentage of mechanical damage based on the mean of the replicates. The results were expressed as percentage of seeds.

The tetrazolium salt test was conducted using the procedure described by França Neto et al. (1998), that is, two sub-samples of 50 seeds were used for each replicate (experimental plot). The samples were pre-conditioned between paper towels moistened with a quantity of water equivalent to 2.5 times the substrate mass, for $16 \mathrm{~h}$ at $25^{\circ} \mathrm{C}$. Then, the seeds were placed in plastic containers and kept submerged in $0.075 \%$ 2,3,5-triphenyl tetrazolium chloride solution, at $40{ }^{\circ} \mathrm{C}$ in the dark, for $150 \mathrm{~min}$. After this period, the seeds were washed in running water and analyzed one by one, computing the number of injured seeds, dead seeds, dead seeds due to severe damage to the embryo and dead seeds due to severe damage to the cotyledon (Figure 2 ). The results were expressed as percentage of seeds.

The seedling emergence test was conducted using four sub-samples of 50 seeds, per treatment, sown in pots filled with sand moistened with water in a quantity equivalent to 2.5 times the paper mass. The pots were kept in a greenhouse under controlled environment at $25{ }^{\circ} \mathrm{C}$ and the evaluations followed the criteria established by Brasil (1992).

Seed vigor was evaluated by the accelerated aging test, carried out with four sub-samples of 50 seeds, which were placed on an aluminum screen and distributed in a single layer in plastic boxes containing $40 \mathrm{~mL}$ of distilled water at the bottom. The plastic boxes were covered with a lid and kept in a regulated incubator at a constant temperature of $41^{\circ} \mathrm{C}$, for $48 \mathrm{~h}$ (Marcos Filho, 1999). After the aging period, the seeds were subjected to the germination test, according to the Rules for Seed Analysis (Brasil, 1992), and a single evaluation was performed at five days, computing the percentage of normal seedlings.

Data were subjected to Shapiro-Wilk normality test and Levene homoscedasticity test, both at $\mathrm{p} \leq 0.05$. Subsequently, the normal data were subjected to analysis of variance by $F$ test

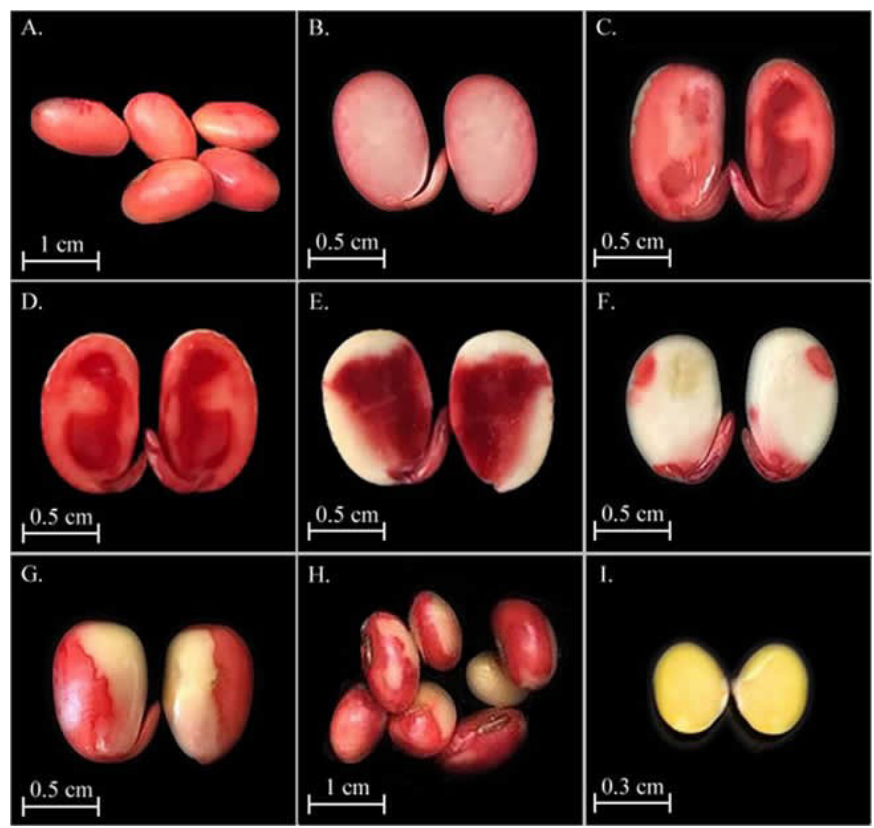

Figure 2. Separation and classification of soybean seeds subjected to tetrazolium test. (A) normal seeds; (B) normal seeds without damage to cotyledons and embryo; (C) normal seeds with lesions in the cotyledons; (D) normal seeds with lesions in the cotyledons and embryo; (E) seeds injured in the coat with damage to the cotyledons and embryo; $(\mathrm{F})$ injured seeds without respiratory activity in the cotyledons and injured embryo; $(G)$ seeds injured in the coat; $(H)$ injured seeds; (I) hard seed 
( $p \leq 0.05$ ) and, when significant, the means were analyzed by Tukey test at $\mathrm{p} \leq 0.05$ using the $\mathrm{R}$ software (R Development Core Team, 2015).

\section{Results AND Discussion}

Seed yield increased in both soybean cultivars when they were co-inoculated with Bacillus subtilis strains (Figure 3A). In the cultivar Desafio, inoculations with $2 \mathrm{~mL} \mathrm{~kg}^{-1}$ of the ST713 strain and $2 \mathrm{~mL} \mathrm{~kg}^{-1}$ of the Pant001 strain resulted in increments of 25 and $18 \%$, compared to the control treatment (without co-inoculation $-0 \mathrm{~mL} \mathrm{~kg}^{-1}$ of B. subtilis), respectively. Likewise, the cultivar M7110 obtained increments in grain yield of 17.5 and $15 \%$ with the inoculation of the Pant001 strain at doses of 3 and $5 \mathrm{~mL} \mathrm{~kg}^{-1}$, respectively, compared to the control.

Inoculation with Bacillus subtilis can favor soybean development, especially in the biological control of plants, production of natural antibiotics and protective effect against secondary soil phytopathogens (Araújo \& Marchesi, 2009; Kuhn \& Pascholati, 2010; Pavan et al., 2011; Gagné-Bourque et al., 2015; Jardin, 2015), in addition to the growth and development of the root system, and consequently greater absorption of water and nutrients (Hungria et al., 2013; Ji et al., 2014; Galindo et al., 2018). Thus, it would be possible to obtain an increase in soybean seed yield, as verified in the present study, without the statistical increment in grain mass.

The interactions between cultivars and evaluated doses were significant for the concentrations of total proteins in the grains, as well as their fractions. For the albumin fraction, seeds inoculated with $3 \mathrm{~mL} \mathrm{~kg}^{-1}$ of the Pant001 strain in the cultivar Desafio led to lower concentration compared to the control, $145.83 \mathrm{mg}$ protein $\mathrm{g}^{-1} \mathrm{FM}$, a reduction equivalent to $25 \%$ (Figure 4A). For the cultivar M7110, the albumin concentration in the seeds did not differ. Albumin concentrations were higher in the cultivar M7110, regardless of strain or dose of B. subtilis applied (Figure 4A).

Inoculation with $4 \mathrm{~mL} \mathrm{~kg}^{-1}$ of B. subtilis Pant001 strain in plants of the cultivar Desafio caused seeds with the highest concentrations of globulin and glutelin (Figures $4 \mathrm{~B}$ and D). There were increments of $58 \%$ in the globulin fraction and
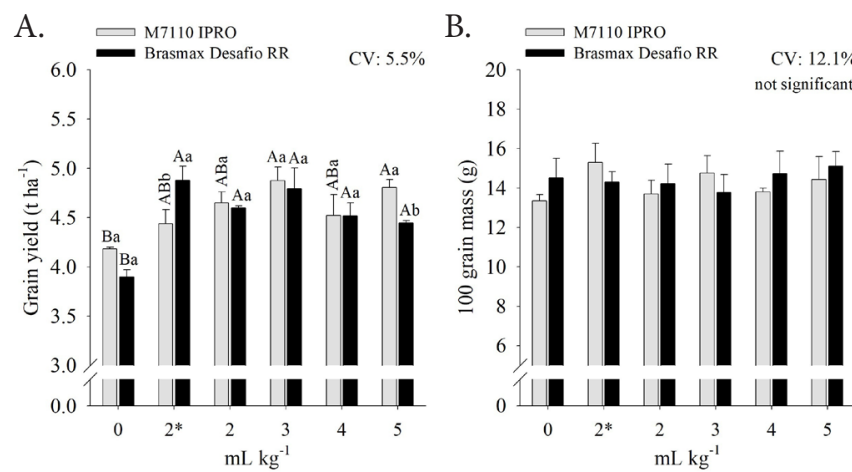

CV - Coefficient of variation. Uppercase letters classify means between doses and lowercase letters classify means between soybean cultivars, according to Tukey test at $\mathrm{p} \leq 0.05$. Bars represent standard error of the means $(n=4)$

$2^{*}$ corresponds to the treatment with the QST713 strain at dose of $2 \mathrm{~mL} \mathrm{~kg}$

Figure 3. (A) Grain yield and (B) grain mass of two cultivars of soybean (Glycine max) subjected to different doses and strains of Bacillus subtilis
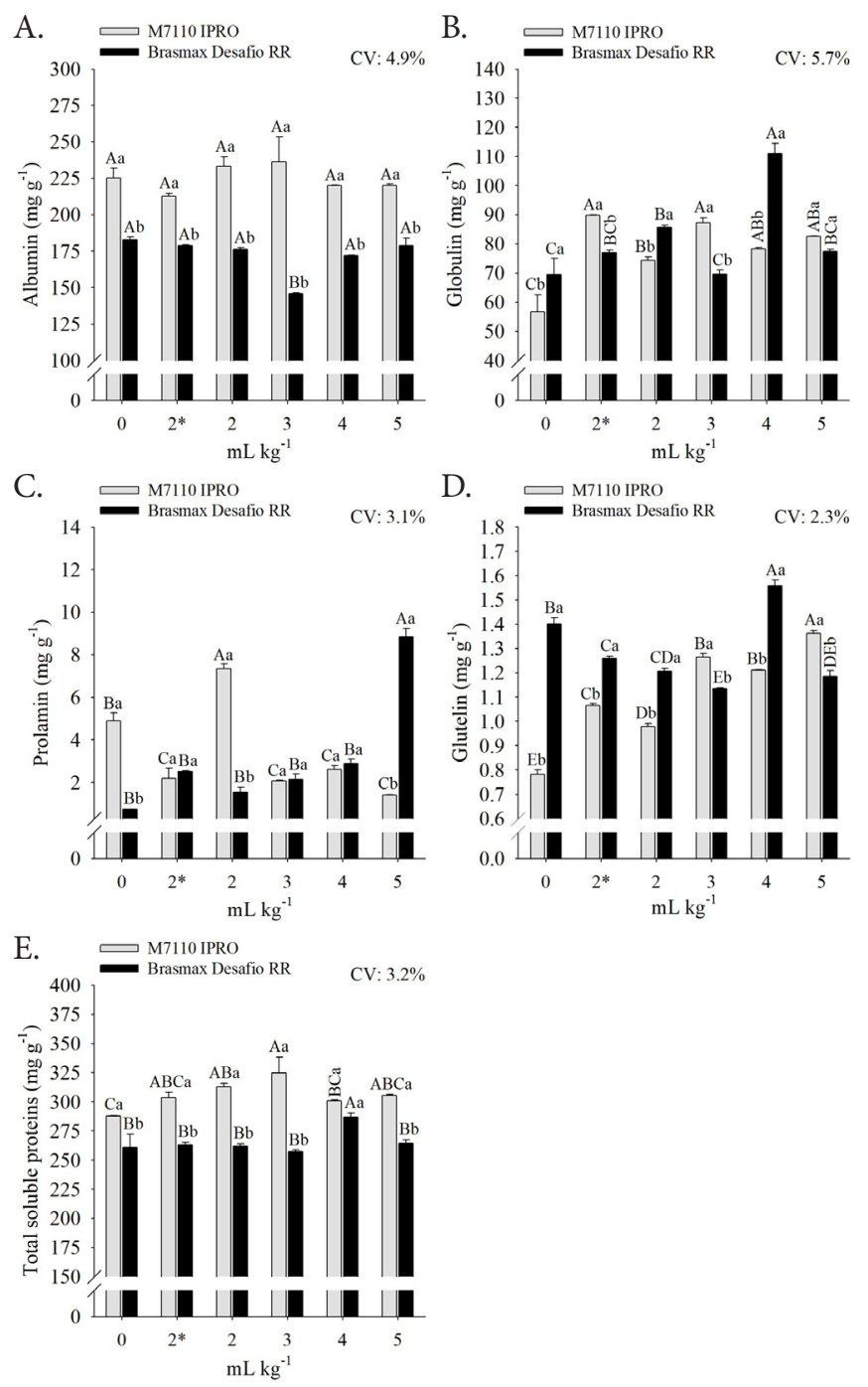

CV - Coefficient of variation. Uppercase letters classify means between doses and lowercase letters classify means between soybean cultivars, according to Tukey test at $\mathrm{p} \leq 0.05$. Bars represent standard error of the means $(\mathrm{n}=4)$

$2^{*}$ corresponds to the treatment with the QST713 strain at dose of $2 \mathrm{~mL} \mathrm{~kg}$

Figure 4. (A) Albumin, (B) globulin, (C) prolamin and (D) glutelin protein fractions and total soluble proteins (E) in seeds of two cultivars of soybean (Glycine max) subjected to different doses and strains of Bacillus subtilis

$11 \%$ in the glutelin fraction, compared to the control treatment $\left(0 \mathrm{~mL} \mathrm{~kg}^{-1}\right)$. With the application of $5 \mathrm{~mL} \mathrm{~kg}^{-1}$ of the Pant001 strain, there was a $91 \%$ increase in the prolamin concentration of the cultivar Desafio (Figure 4C).

With the application of B. subtilis Pant001 strain and QST713 strain at a dose of $2 \mathrm{~mL} \mathrm{~kg}^{-1}$, the globulin fraction concentration increased in the cultivar M7110 (Figure 4B). The application of the $2 \mathrm{~mL} \mathrm{~kg}^{-1}$ dose of the Pant001 strain led to higher concentration of prolamin, but the $2 \mathrm{~mL} \mathrm{~kg}^{-1}$ dose of the QST713 strain reduced this protein fraction compared to control in the cultivar M7110 (Figure 4C).

Increasing doses of the inoculant Pant001 strain and the application of $2 \mathrm{~mL} \mathrm{~kg}^{-1}$ of the QST713 strain increased the glutelin concentration in the cultivar M7110. For the cultivar Desafio, the application of $4 \mathrm{~mL} \mathrm{~kg}^{-1}$ of the Pant001 strain increased glutelin concentration, but the application of $2 \mathrm{~mL}$ $\mathrm{kg}^{-1}$ of the QST713 strain reduced the concentration of this fraction compared to the control treatment (Figure 4D). The cultivar Desafio had higher concentrations of glutelin in the 
absence of co-inoculation, at the doses of $2 \mathrm{~mL} \mathrm{~kg}^{-1}$ of the QST713 strain and 2 and $4 \mathrm{~mL} \mathrm{~kg}^{-1}$ of the Pant001 strain; however, the cultivar M7110 had higher concentrations of glutelin under the doses of 3 and $5 \mathrm{~mL} \mathrm{~kg}^{-1}$ of the Pant001 strain (Figure 4D).

The application of 3 and $4 \mathrm{~mL} \mathrm{~kg}^{-1}$ of the Pant001 strain in the cultivars M7110 and Desafio increased the amount of total storage proteins compared to the control, with increments of 16.1 and $9.6 \%$ in the concentrations, respectively. In the absence of co-inoculation, with the application of $2 \mathrm{~mL} \mathrm{~kg}^{-1}$ of the QST713 strain and 2, 3 and $5 \mathrm{~mL} \mathrm{~kg}^{-1}$ of the Pant001 strain, the cultivar M7110 had higher concentration of total storage proteins (Figure 4E).

The increment in total protein concentration suggests that there was an increase in $\mathrm{N}$ absorption and accumulation by the soybean crop, since this nutrient is related to the synthesis of proteins, chlorophyll, coenzymes, phytohormones, nucleic acids and secondary metabolites (Marschner, 2012). Moreover, this is an excellent result because of the increase in the quality of the harvested soybean seeds.

According to Bárbaro et al. (2009), the literature reports that bacteria called PGPB (plant growth-promoting bacteria), such as $B$. subtilis, can act on the relationship between the rhizobium and leguminous species, promoting plant growth and increments in grain and seed yield and in the total biologically fixed $\mathrm{N}$, in addition to improvements in the use of $\mathrm{N}$ obtained by the plant due to the co-inoculation, corroborating the results verified in the present study.

These effects may be caused by several mechanisms, including early beginning and/or longer duration of BNF in the nodules, increment in nodule mass, promotion of increase in the total volume of roots and secondary roots, which would increase the sites of infection of these beneficial microorganisms, inhibition of pathogens and diseases, production of phytohormones and accumulation of nutrients (Bárbaro et al., 2009).

In addition, as stated by Hungria et al. (2013), these effects promoted by the co-inoculation with PGPB and rhizobium appear to be influenced by specific signals between the bacterial strains and plant cultivars. Thus, new research studies on the response of co-inoculation according to the cultivars are important for understanding and developing genetic materials that are more responsive to the strains of commercial microorganisms. Therefore, the importance of this study is justified, since it demonstrates that there are differences in the interaction between cultivars and strains and doses of inoculants.

The results obtained in the mechanical damage test indicated high levels of damage to the grains, with an occurrence higher than $10 \%$ in all treatments evaluated (Figure $5 \mathrm{~A})$. The greatest damage occurred to the cultivar M7110 subjected to the dose of $2 \mathrm{~mL} \mathrm{~kg}^{-1}$ of the QST713 strain and to the application of 4 and $5 \mathrm{~mL} \mathrm{~kg}^{-1}$ of the Pant 001 strain, which increased the occurrence of mechanical damage by $45,32.5$ and $36 \%$, respectively. For the cultivar Desafio, there was no increase in the occurrence of mechanical damage among the proposed treatments (Figure 5A).

The test of detection of mechanical damage in grains is directly correlated with the moisture content and size of the
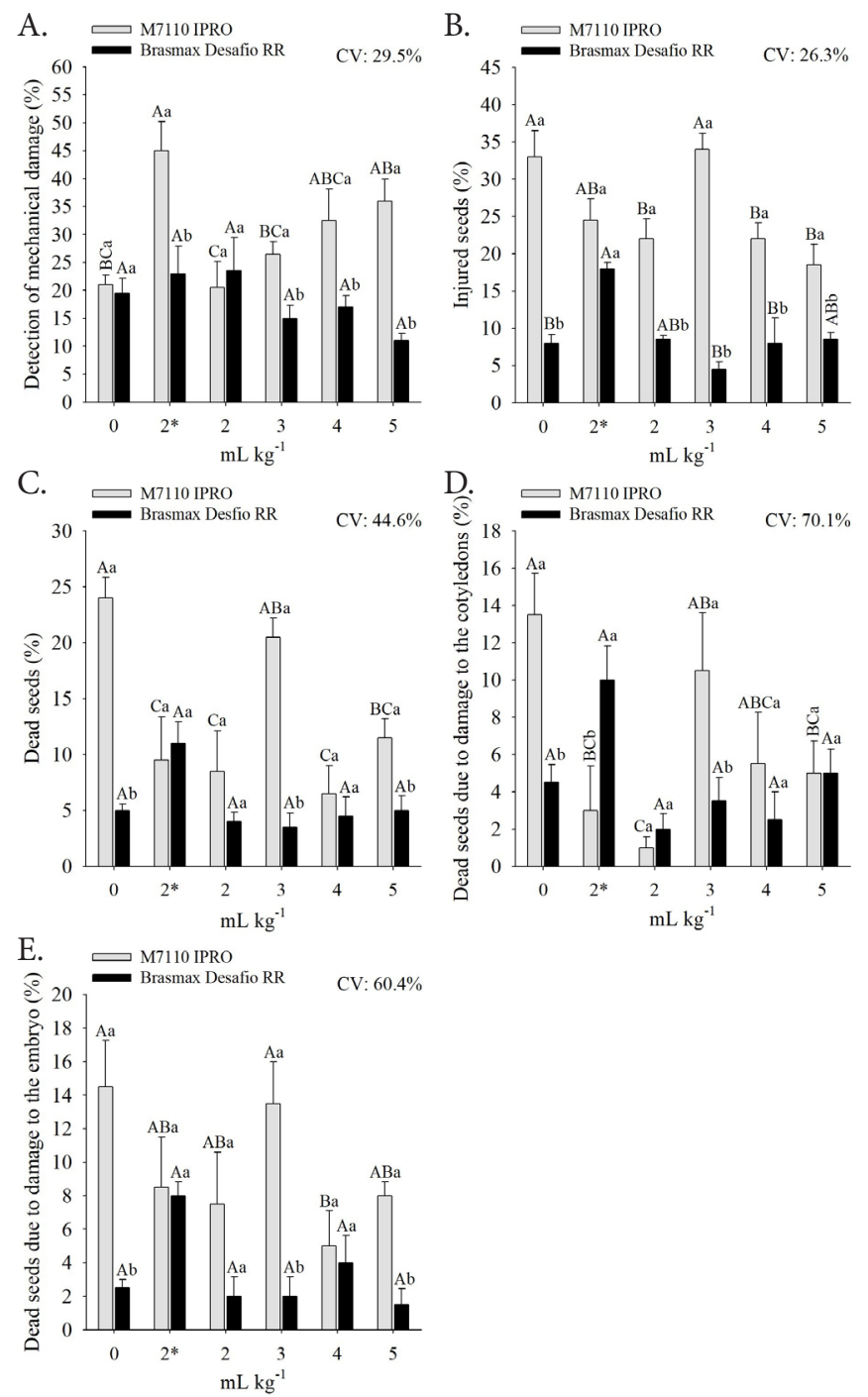

CV - Coefficient of variation. Uppercase letters classify means between doses and lowercase letters classify means between soybean cultivars, according to Tukey test at $\mathrm{p} \leq 0.05$. Bars represent standard error of the means $(n=4)$

$2^{*}$ corresponds to the treatment with the QST713 strain at dose of $2 \mathrm{~mL} \mathrm{~kg}$

Figure 5. Detection of mechanical damage (A), injured seeds (B), dead seeds (C), dead seeds due to damage to the cotyledons (D) and dead seeds due to damage to the embryo (E) in two cultivars of soybean (Glycine max) subjected to different doses and strains of Bacillus subtilis

seeds, due to the fragility of the coat and cotyledons, and may be associated with the increase in grain mass. At the time of threshing, moisture contents in the cultivar M7110 were close to $22.8 \%$ in the control treatment, $22.7 \%$ in the treatment with $2^{*} \mathrm{~mL} \mathrm{~kg}^{-1}, 22.7 \%$ with $2 \mathrm{~mL} \mathrm{~kg}{ }^{-1}, 22.5 \%$ with $3 \mathrm{~mL} \mathrm{~kg}$ 1, 23.6\% with $4 \mathrm{~mL} \mathrm{~kg}^{-1}$ and $22.5 \%$ with $5 \mathrm{~mL} \mathrm{~kg}^{-1}$. For the cultivar Desafio, the moisture contents were around $22.7 \%$ in the control treatment, $24.2 \%$ in the treatment with $2^{*} \mathrm{~mL}$ $\mathrm{kg}^{-1}, 22.6 \%$ with $2 \mathrm{~mL} \mathrm{~kg}^{-1}, 22.6 \%$ with $3 \mathrm{~mL} \mathrm{~kg}^{-1}, 22 \%$ with 4 $\mathrm{mL} \mathrm{kg}^{-1}$ and $23.2 \%$ with $5 \mathrm{~mL} \mathrm{~kg}^{-1}$, which are considered high for mechanical threshing. According to Holtz \& Reis (2013), for lower losses and damage to the seeds, the ideal moisture content in grains for mechanized harvesting of soybean is between 12 and $14 \%$, so waiting for the natural drying of soybean seeds in the field would be advantageous considering the reduction in mechanical damage.

The tetrazolium salt staining test indicated a higher occurrence of seeds with lesions in the coat under the 
application of 0 (absence of B. subtilis inoculation) and $3 \mathrm{~mL}$ $\mathrm{kg}^{-1}$ of the Pant001 strain applied to the cultivar M7110, which had 33 and $34 \%$ of lesions, respectively (Figure 5B). In relation to the Desafio cultivar, only the seeds subjected to the dose of $2 \mathrm{~mL} \mathrm{~kg}^{-1}$ of the QST713 strain were affected, with damage of $18 \%$ to the coat (Figure 5B).

The results obtained for seeds with damage to the coat are similar to those obtained for dead seeds due to damage to the embryo (Figure 5B). The occurrence of dead seeds, without respiratory activity, in the tissues of the cultivar M7110 subjected to doses of 0 and $3 \mathrm{~mL} \mathrm{~kg}^{-1}$ of the Pant001 strain respectively led to 14.5 and $13.5 \%$ of grains with severe damage to the embryo. These same treatments stood out from the others with respect to the number of dead seeds with severe damage to the cotyledons, 13.5 and $10.5 \%$, respectively (Figures 5C and D).

Among the treatments evaluated, the absence of coinoculation with B. subtilis and application of the dose of $3 \mathrm{~mL}$ $\mathrm{kg}^{-1}$ of the Pant001 strain applied to the cultivar M7110 were harmful to the number of dead seeds, while for the cultivar Desafio, there was no difference between doses and strains (Figure 5B).

It is worth pointing out that, despite the increase in mechanical damage with the co-inoculation of the QST713 strain at dose of $2 \mathrm{~mL} \mathrm{~kg}^{-1}$ and injuries in the coat caused by the co-inoculation of the Pant001 strain at dose of $3 \mathrm{~mL} \mathrm{~kg}^{-1}$ in the cultivar M7110, in general, there was an increase in seedling emergence and seed vigor, which indicates that the co-inoculation did not adversely affect the quality of soybean seeds.

The interaction between cultivars and doses of $B$. subtilis was significant for seedling emergence. The application of 4 $\mathrm{mL} \mathrm{kg}{ }^{-1}$ of Bacillus subtilis Pant001 strain resulted in a higher percentage of emergence compared to the control treatment (Figure 6A). The cultivar Desafio had a 66\% increase in the number of emerged plants, while the cultivar M7110 had a 70\% increase in germination. In treatments with application of 0 (control) and $2 \mathrm{~mL} \mathrm{~kg}^{-1}$ of B. subtilis, the cultivar Desafio had 21 and 54\% higher number of emerged seedlings compared to cultivar M7110, respectively (Figure 6A).
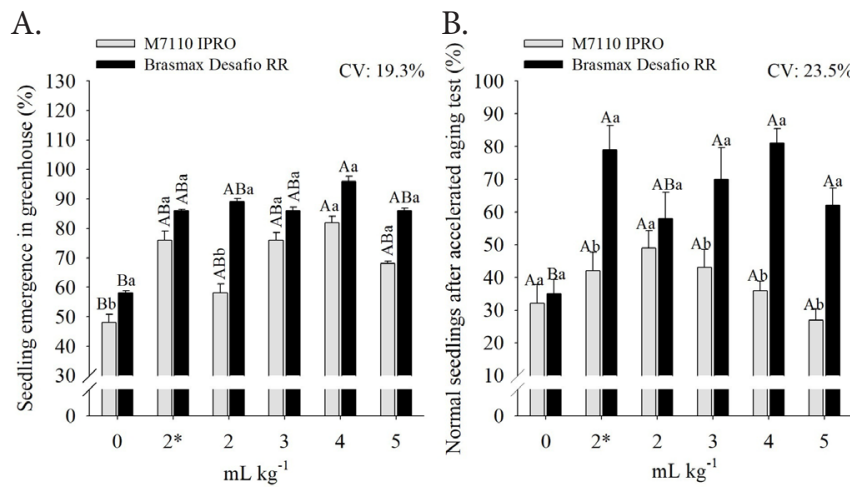

CV - Coefficient of variation. Uppercase letters classify means between doses and lowercase letters classify means between soybean cultivars, according to Tukey test at $\mathrm{p} \leq 0.05$. Bars represent standard error of the means $(\mathrm{n}=4)$

$2^{*}$ corresponds to the treatment with the QST713 strain at dose of $2 \mathrm{~mL} \mathrm{~kg}^{-1}$

Figure 6. (A) Seedling emergence in greenhouse and (B) normal seedlings after accelerated aging test of two cultivars of soybean (Glycine max) subjected to different doses and strains of Bacillus subtilis
Regarding seed vigor evaluated by the accelerated aging test, there was an effect of interaction between doses of $B$. subtilis and soybean cultivars. For the cultivar Desafio, the doses of 3, 4 and $5 \mathrm{~mL} \mathrm{~kg}^{-1}$ of the Pant001 strain and $2 \mathrm{~mL} \mathrm{~kg}^{-1}$ of the QST713 strain resulted in increments of 100, 131, 77 and $125 \%$ in normal seedlings compared to the control treatment. On the other hand, the cultivar M7110 did not differ between doses and strains (Figure 6B).

As observed in the germination test, there was a difference in seed vigor as a function of the cultivars at the doses of 3,4 and $5 \mathrm{~mL} \mathrm{~kg}^{-1}$ with the Pant001 strain and $2 \mathrm{~mL} \mathrm{~kg}^{-1}$ with the QST713 strain (Figure 6B ). The cultivar Desafio had greater vigor compared to the cultivar M7110, with increments of 63, 125 and $130 \%$ in the number of normal plants at doses of 3, 4 and $5 \mathrm{~mL} \mathrm{~kg}^{-1}$ respectively, with the Pant001 strain, and 88\% at the dose of $2 \mathrm{~mL} \mathrm{~kg}^{-1}$ with the QST713 strain.

The positive results obtained in the present study highlight the potential of co-inoculation with B. subtilis in the quality and yield of soybean seeds, especially because it is a low-cost and low-investment technique with easy application and use, non-pollutant, and that is inserted in a sustainable context desired in modern agriculture.

\section{Conclusions}

1. The inoculation of Bacillus subtilis Pant001 and QST713 strains promotes yield increments in both soybean cultivars tested, besides improving seed quality due to the increase in seedling emergence percentage and seed vigor.

2. The use of Bacillus subtilis Pant001 strain at the dose of $3 \mathrm{~mL} \mathrm{~kg}^{-1}$ leads to better response for the soybean cultivar M7110, while the Pant001 and QST713 strains at dose of $2 \mathrm{~mL}$ $\mathrm{kg}^{-1}$ favor the cultivar Desafio, increasing seed yield and the amount of storage proteins of both cultivars.

\section{Literature Cited}

Ambrosano, E. J.; Tanaka, R. T.; Mascarenhas, H. A. A.; Raij, B. van; Quaggio, J. A.; Cantarella, H. Leguminosas e oleaginosas. In: Raij, B. van; Cantarella, H.; Quaggio, J. A.; Furlani, A. M. C. Recomendações de calagem e adubação para o Estado de São Paulo. Campinas: Instituto Agronômico de Campinas, 1997. 285p. Boletim Técnico, 100

Araújo, F. F. D.; Marchesi, G. V. P. Uso de Bacillus subtilis no controle da meloidoginose e na promoção do crescimento do tomateiro. Ciência Rural, v.39, p.1558-1561, 2009. https://doi.org/10.1590/ S0103-84782009000500039

Bárbaro, I. M.; Centurio, M. A. P. da C.; Gavioli, E. A.; Sarti, D. G. P.; Bárbaro Júnior, L. S.; Ticelli, M.; Miguel, F. B. Análise de cultivares de soja em resposta à inoculação e aplicação de cobalto e molibdênio. Revista Ceres, v.56, p.342-349, 2009. https://doi. org/10.5747/ca.2009.v05.n1.a0040

Bishnoi, U.; Polson, S.W.; Sherrier, D. J.; Bais, H. P. Draft genome sequence of a natural root isolate, Bacillus subtilis UD1022, a potential plant growth-promoting biocontrol agent. Genome Announcements, v.3, p.1-2, 2015. https://doi.org/10.1128/ genomeA.00696-15 
Bradford, M. A rapid and sensitive method for the quantitation of microgram quantities of protein utilizing the principle of proteindye binding. Analytical Biochemistry, v.72, p.248-254, 1976. https://doi.org/10.1006/abio.1976.9999

Brasil. Ministério da Agricultura. Regras para análise de sementes. Brasília: MAPA, 1992. 365p.

CONAB - Companhia Nacional de Abastecimento. Acompanhamento de safra brasileira: Grãos. Brasília: CONAB, 2019. 113p.

França Neto, J. B.; Krzyzanowski, F. C.; Costa, N. P. The tetrazolium test for soybean seeds.Londrina: Embrapa Soja, 1998. 71 p. Documents, 115

Gagné-Bourque, F.; Mayer, B. F.; Charron, J.-B.; Vali, H.; Bertrand, A.; Jabaji, S. Accelerated growth rate and increased drought stress resilience of the model grass Brachypodium distachyon colonized by Bacillus subtilis B26. Plos One, v.10, p.e0130456, 2015. https:// doi.org/10.1371/journal.pone.0130456

Galindo, F. S.; Teixeira Filho, M. C. M.; Buzetti, S.; Ludkiewicz, M. G. Z.; Rosa, P. A. L.; Tritapepe, C. A. Technical and economic viability of co-inoculation with Azospirillum brasilense in soybean cultivars in the Cerrado. Revista Brasileira de Engenharia Agrícola e Ambiental, v.22, p.51-56, 2018. https://doi.org/10.1590/18071929/agriambi.v22n1p51-56

Galindo, F. S.; Teixeira Filho, M. C. M.; Buzetti, S.; Santini, J. M. K.; Alves, C. J.; Ludkiewicz, M. G. Z. Wheat yield in the Cerrado as affected by nitrogen fertilization and inoculation with Azospirillum brasilense. Pesquisa Agropecuária Brasileira, v.52, p.794-805, 2017. https://doi.org/10.1590/s0100-204x2017000900012

Galindo, F. S.; Teixeira Filho, M. C. M.; Buzetti, S.; Santini, J. M. K.; Alves, C. J.; Nogueira, L. M.; Ludkiewicz, M. G. Z.; Andreotti, M.; Bellote, J. L. M. Corn yield and foliar diagnosis affected by nitrogen fertilization and inoculation with Azospirillum brasilense. Revista Brasileira de Ciência do Solo, v.40, p.e015036, 2016. https://doi. org/10.1590/18069657rbcs20150364

Holtz, V.; Reis, E. F. dos. Perdas na colheita mecanizada de soja: Uma análise quantitativa e qualitativa. Revista Ceres, v.60, p.347-353, 2013. https://doi.org/10.1590/S0034-737X2013000300007

Hungria, M.; Nogueira, M. A.; Araujo, R. S. Co-inoculation of soybeans and common beans with rhizobia and azospirilla: Strategies to improve sustainability. Biology and Fertility of Soils, v.49, p.791-801, 2013. https://doi.org/10.1007/s00374-012-0771-5

Jardin, P. Plant biostimulants: Definition, concept, main categories and regulation. Scientia Horticulturae, v.196, p.3-14, 2015. https:// doi.org/10.1016/j.scienta.2015.09.021
Ji, S. H.; Gururani, M. A.; Chun, S. C. Isolation and characterization of plant growth promoting endophytic diazotrophic bacteria from Korean rice cultivars? Microbiological Research, v.169, p.83-98, 2014. https://doi.org/10.1016/j.micres.2013.06.003

Kuhn, O. J.; Pascholati, S. F. Custo adaptativo da indução de resistência em feijoeiro mediada pela rizobactéria Bacillus cereus ou acibenzolar-S-metil: Atividade de enzimas, síntese de fenóis e lignina e biomassa. Summa Phytopathologica, v.36, p.107-114, 2010. https://doi.org/10.1590/S0100-54052010000200001

Marcos Filho, J. Teste de envelhecimento acelerado. Vigor de sementes: Conceitos e testes. Londrina: ABRATES, 1999. p.1-24.

Marschner, P. Marschner's mineral nutrition of higher plants. 3.ed. New York: Academic Press, 2012. 651p.

Moretti, L. G.; Lazarini, E.; Bossolani, J. W.; Parente, T. L.; Caioni, S.; Araujo, R. S.; Hungria, M. Can additional inoculations increase soybean nodulation and grain yield? Agronomy Journal, v.110, p.1-7, 2018. https://doi.org/10.2134/agronj2017.09.0540

Pavan, M. E.; Pettinari, M. J.; Cairó, F.; Pavan, E. E.; Cataldi, A. A. Bacillus anthracis: Una mirada molecular a un patógeno célebre. Revista Argentina de Microbiología, v.43, p.294-310, 2011.

R Development Core Team. R: A language and environment for statistical computing. Available on: <https://www.R-project.org/> Accessed on: Set. 2018.

Raij, B. van; Andrade, J. C.; Cantarella, H.; Quaggio, J. A. Análise química para avaliação da fertilidade de solos tropicais. Campinas: Instituto Agronômico de Campinas, 2001. 285p.

Reis, H. P. G.; Barcelos, J. P. Q.; Furlani Junior, E.; Santos, E. F.; Silva, V. M.; Moraes, M. F.; Putti, F. F.; Reis, A. R. dos. Agronomic biofortification of upland rice with selenium and nitrogen and its relation to grain quality. Journal of Cereal Science, v.79, p.508-515, 2018. https://doi.org/10.1016/j.jcs.2018.01.004

Sá, J. C. M.; Lal, R.; Cerri, C. C.; Lorenz, K.; Hungria, M.; Carvalho, P. C. C. Low-carbon agriculture in South America to mitigate global climate change and advance food security. Environment International, v.98, p. 102-112, 2017. https://doi.org/10.1016/j. envint.2016.10.020

Singh, A.; Gupta, R.; Pandey, R. Rice seed priming with picomolar rutin enhances rhizospheric Bacillus subtilis CIM colonization and plant growth. Plos One, v.11, p.1-17, 2016. https://doi. org/10.1371/journal.pone.0146013

Tahir, H. A. S.; Gu, Q.; Wu, H.; Raza, W.; Hanif, A.; Wu, L.; Colman, M. V.; Gao, X. Plant growth promotion by volatile organic compounds produced by Bacillus subtilis SYST2. Frontiers in Microbiology, v.8, p.1-11, 2017. https://doi.org/10.3389/fmicb.2017.00171 